\title{
A Case Study on Performance of Jia Bharali River Bank Protection Measure Using Geotextile Bags
}

\author{
Utpal Kumar Das ${ }^{1}$
}

Received: 6 March 2016/Accepted: 6 April 2016/Published online: 22 April 2016

(C) Springer International Publishing Switzerland 2016

\begin{abstract}
River bank erosion is one of the major natural disasters being faced by the state of Assam, located in the North-eastern part of India. With the increasing popularity of geotextile materials in construction industry several pilot projects to control bank erosion of major rivers of Assam have recently been executed with the application of geotextile bags, geotextile tubes. But very little scientific study on the post-construction performance of these works is available. In this paper the findings of a study on the post construction performance of one of these recently completed bank protection works is presented. In order to ascertain the erodibility of the bank soil characterisation of geotechnical properties of the bank soil is carried out. The bore $\log$ obtained by adopting a simplified method of boring suitable for this investigation is presented along with detailed laboratory test results and analysis. The change in river flow pattern near the bank after installation of the bank protection work and the resultant siltation is studied in this work. In order to predict progressive development of sand bar due to the induced siltation during the first 1 year after installation of the protection work the siltation area is surveyed and the contours are prepared. The resultant flow pattern is reasonably determined from the siltation area contours. Satellite images of the study area for a period of 3 years after installation of the protection work are analysed and presented before arriving at a final conclusion on the performance of the protection measure.
\end{abstract}

Utpal Kumar Das

ukrdas@gmail.com

1 Department of Civil Engineering, Tezpur University, Napam, Tezpur, Assam 784028, India
Keywords Erosion - Bank protection - Geotextile bags · Siltation $\cdot$ Sand-bars

\section{Introduction}

River bank erosion is one of the major natural disasters being faced by the state of Assam, located in the Northeastern part of India. Over the last 100 years mighty river Brahmaputra, which runs $740 \mathrm{~km}$ through the State of Assam, has shown a general trend of widening wiping out more than 4500 villages. The Brahmaputra which occupied around $4000 \mathrm{~km}^{2}$ in 1920 has expanded to about $6000 \mathrm{~km}^{2}$ in 2010 along the flood plains of Assam [1]. Brahmaputra and most of its tributaries in its north bank have originated mostly from the Himalayan range. A sudden decrease in slopes of these rivers as they enter its flood plains in Assam result in a large amount of sediment deposition, giving rise to development of braiding pattern of the river. With the commencement of flood season, the sediment transport in these rivers increase, the thalweg starts to change position and geometry and location of mid-channel bars change. As the flow begins to recede, deposition over the bed takes place in the form of bars and islands. The rivers flow in several sinuous channels in between these sandbars.

Kotoky et al. [2] from their study on nature of bank erosion of the braided Brahmaputra river channel evidenced significant erosion on both banks during the period 1914-1975, while during 1975-1998 the river witnessed a dominant phase of deposition.

Jiyabharali and Subansiri are two major tributaries of Brahmaputra in its northern bank. Both the two tributaries have originated from the Himalayan range and have similar braiding characteristic in the flood plains of Assam. 
Subansiri has drawn more attention of researchers than Jia Bharali due to its hydro-electric power potential. Gogoi and Goswami [3] in their study of bank-line migration pattern of Subansiri river using satellite imagery of 1995 and 2010 found that the total erosion $\left(82 \mathrm{~km}^{2}\right)$ on both banks is double that of deposition $\left(43 \mathrm{~km}^{2}\right)$ during this 15 -year period of study. The Subansiri river is characterised by heavy flow during flood season, enormous volume of sediment load, continuous change in channel morphology, bankline migration and lateral changes in channels which further causes severe bank erosion leading to a considerable loss of good fertile land every year [4]. The great earthquake that hit Assam in 1950 disturbed the balance between sediment supply and transportation of Subansiri river and this additional sediment resulted in mid-channel bar formation, bank erosion and widening [5]. The average suspended sediment load of Subansiri and Jia Bharali are reported as 1776 and 2013 ha $\mathrm{m}$, respectively [6, 7].

Construction of spurs, use of porcupines and boulder pitching of banks are the common measures taken up to contain bank erosion in these rivers of Assam. Government agencies take up the primary responsibility of executing and maintaining these protection measures. With the increasing popularity of geotextile materials in construction industry several pilot projects to control bank erosion of major rivers of Assam have recently been executed with the application of geotextile bags, geotextile tubes, etc.

Mondal et al. [8] through a case study on embankment breaching in Moyna drainage basin area of West Bengal, India, investigated the physical, mechanical and geotechnical properties of the embankment material and evaluated existing design methodology for embankment stability analysis. As locally available soil was used in construction of the earthen embankments the study found that the geotechnical properties of embankment materials needed to be improved by using additives or reinforcing materials like soil-cement, natural or geosynthetic fiber. It was also suggested use of geotextile bags, cement composites with reinforcement for embankment slope protection.

Geotextile tubes, Geotextile bags are also being experimented in selected stretches of banks of river Brahmaputra and its major tributaries. Maurya et al. [9] have given a detailed account of the recent flood protection and antierosion works designed and executed using geotextile to provide protection of the bed and bank erosion of the Brahmaputra river. Bank protection followed by a suitable bed protection was carried out using geotextile bags placed on geotextile filter layer. Steel Gabions filled with geotextile bags were placed at regular intervals to impart further stability to the scour protection measure. Maurya et al. [10] studied the material properties of the geosynthetics used in river training works of river Dibang, a tributary of Brahmaputra, and discussed the advantages of using these geotextile bags over conventional materials and methods.

Very little study on the post-construction performance of these bank protection measures using geotextile bags in flood plains of river Brahmaputra is available in literature. In this work a study on the effects of Jia Bharali river bank protection work, executed by Water Resources Department of Assam under one of its pilot projects using geotextile bags, on the induced siltation and flow pattern of the river is taken up.

Research [11, 12] has shown that differential physical properties of cohesive and non-cohesive bank materials result in marked differences in erosion rates, erosion processes and failure modes. Although fine-grained materials are resistant to fluid shear, they tend to have low shear strength and are susceptible to mass failure. To acquire appropriate understanding of mass failure problem like erosion the characterization geotechnical properties of the bank soil is also undertaken in this work.

\section{The Study Area}

A stretch of western bank of Jia Bharali river near Tezpur town of Assam had continuously been subjected to erosion every year during the floods since last several years. The progression of the river into the land due to erosion resulted in breaching of an existing embankment and was perceived as a threat to the Tezpur Central University, situated about $1.5 \mathrm{~km}$ away. The Water Resource Department, Assam, in the year 2012, had taken up a pilot project for protection of this stretch of the river bank. The measure consisted of installation of a launching apron up to low water level (LWL) and boulder pitching of river bank above LWL. Application of geotextile was made in the form of geotextile bags for construction of the launching apron. A satellite map of the location is shown in Fig. 1.

Length of this bank protection work is $650 \mathrm{~m}$, located from Lat. $26^{\circ} 42^{\prime} 53^{\prime \prime}$ Long. $92^{\circ} 51^{\prime} 2^{\prime \prime}$ to Lat. $26^{\circ} 43^{\prime} 21^{\prime \prime}$ Long. $92^{\circ} 50^{\prime} 58^{\prime \prime}$, about $12 \mathrm{~km}$ upstream from the point of confluence of this tributary and river Brahmaputra.

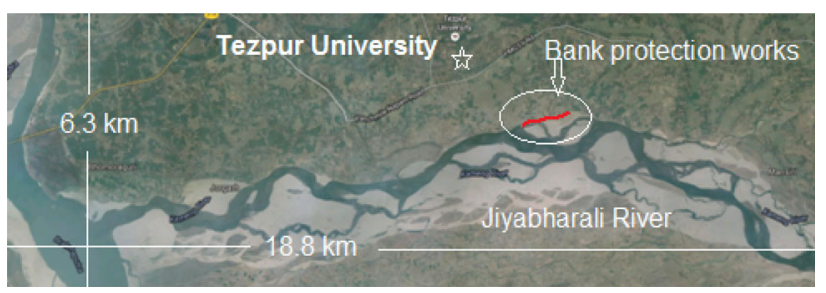

Fig. 1 Satellite map of the study area (from Google Earth, October 2015) 


\section{Field and Laboratory Studies}

Characterization of geotechnical properties of the river bank soil is undertaken in this work in a geotechnical investigation of the Jia Bharali river bank soil at a location near the protection work under study.

The field work constituted of field soil investigation up to ground water table during the dry season. Since the depths of failures due to erosion are generally shallow the soil stratification in fine detail needed to be collected for appropriate slope stability analysis. Both wash boring and auger boring, the most commonly adopted subsurface boring methods, give highly disturbed soil samples and it is difficult to identify thinner strata of subsoil. In order to obtain the soil stratification data in finer detail an alternative and simplified procedure was adopted in this investigation. In this method a hollow galvanized iron pipe of $2.5 \mathrm{~m}$ length, $70 \mathrm{~mm}$ inner diameter and $3 \mathrm{~mm}$ thickness was used and the borehole was taken down by repeated upward-downward movement of the pipe into soil with the help of manual effort. The pipe was taken out of the borehole after every $30 \mathrm{~cm}$ penetration and the soil was carefully taken out of the pipe by gently tapping its outer body. Samples of soil were than collected, sealed in marked containers and transported to the geotechnical engineering laboratory of the Dept. of Civil Engineering, Tezpur University for laboratory testing. The method could be effectively used to collect soil samples for depths up to ground water table. The in situ shear strength of the bank soil at different depths were measured using field vane shear instrument. The test procedure was followed as laid down in Indian standard code of practice [13].

The soil samples collected from field were tested in laboratory for determination of the geotechnical properties of the river bank soil. The shear strength was determined from laboratory testing of remoulded samples prepared at field density. For determination of the shear strength direct shear test was conducted under undrained condition.

\section{Field Surveying}

In the first year after installation of the protection measures fresh siltation was observed in the study area forming sand bars. In order to study the pattern and extent of this induced siltation and formation of the sand bars field surveying was carried out in the siltation area. Electronic Theodolite was used in this surveying work. The survey area was divided into $20 \mathrm{~m} \times 20 \mathrm{~m}$ grid and reduced levels at the grid points were determined with an aim of preparing a contour drawing of the sand bars.

\section{Properties of the River Bank Soil}

The borehole log obtained from the field borehole is shown in Fig. 2. It shows a surface layer of silty sand soil up to a depth of $0.9 \mathrm{~m}$ beyond which the soil is predominantly clayey sand.

The ground water table was encountered at $1.46 \mathrm{~m}$ depth. The stratification of the bank soil could be obtained in finer detail due to adoption of the simplified method of boring.

Table 1 gives the geotechnical properties of the bank soil obtained from laboratory testing of the soil collected from field at different depths.

\section{Description of the River Bank and Installed Bank Protection Work}

The detail of the protection work designed and installed at the river bank by the Water Resources Department (WRD) is shown in Fig. 3 and Table 2.

\section{Properties and Physical Condition of the Geotextile Bag Material}

Samples of unused geotextile bags from the same lot of bags used in the above project were collected for testing. A few geotextile bags, sand-filled in the year 2012, were found unused in the filling site in the river bank and were collected for assessing their physical condition after 3 years of exposure to field condition. The geotextile materials were tested in the laboratory for determination of mass per unit area, thickness, tensile strength and puncture strength. The puncture strength and tensile strength were tested in the CBR instrument using $50 \mathrm{~mm}$ diameter plunger. The CBR test setup was suitably modified as shown in Fig. 4 to carry out these tests. The tensile strength of the geotextile and strain at failure were determined from the CBR puncture test using the following relations [14].

Tensile force per unit width

$$
=\frac{\text { CBR puncture breaking force }}{2 \times \pi \times \text { radius of CBR puncturing plunger }},
$$

Strain at failure $=\frac{(x-a)}{a} \times 100 \%$,

where $x=$ diagonal length of the geotextile at failure; $a=$ horizontal distance between the outer edge of the plunger and the inner edge of the mould.

The geotextile material used in the project is of nonwoven type. A general inspection of the used and unused samples of the geotextile showed that the geotextile, after 3 years of exposure to field condition, has not shown any 
Fig. 2 Bore log obtained from boring of river bank soil

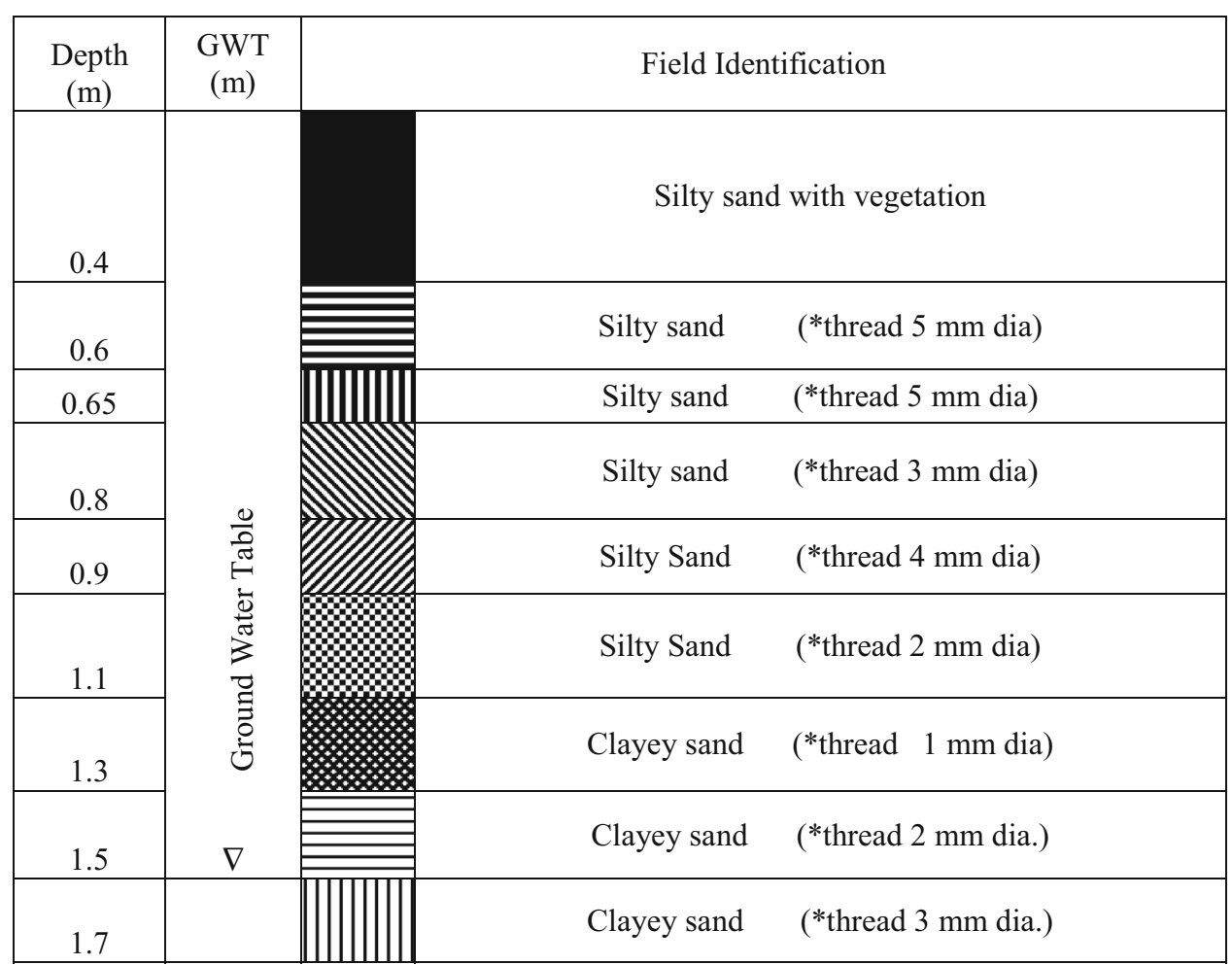

* Diameter at which soil moulded in field moisture content crumble when rolled in thread

Table 1 Geotechnical properties of the river bank soil at five different depths

\begin{tabular}{|c|c|c|c|c|c|c|c|c|c|c|c|}
\hline \multirow{2}{*}{$\begin{array}{l}\text { Depth from } \\
\text { ground } \\
\text { level }(\mathrm{m})\end{array}$} & \multirow{2}{*}{$\begin{array}{l}\text { Dry } \\
\text { Density } \\
(\mathrm{g} / \mathrm{cc})\end{array}$} & \multicolumn{3}{|c|}{ Atterberg limits } & \multirow[t]{2}{*}{$\begin{array}{l}\text { Specific } \\
\text { gravity }\end{array}$} & \multicolumn{2}{|c|}{$\begin{array}{l}\% \text { Finer than } \\
\text { (particle size) }\end{array}$} & \multirow[t]{2}{*}{ Classification } & \multicolumn{2}{|c|}{$\begin{array}{l}\text { Shear parameters obtained } \\
\text { from laboratory test }\end{array}$} & \multirow{2}{*}{$\begin{array}{l}\text { Shear strength } \\
\text { from field vane } \\
\text { shear test }(\mathrm{kPa})\end{array}$} \\
\hline & & $\overline{\mathrm{LL}}$ & PL & $\overline{\text { PI }}$ & & $2 \mathrm{~mm}$ & $\overline{0.075 \mathrm{~mm}}$ & & $c(\mathrm{kPa})$ & $\phi\left(^{\circ}\right)$ & \\
\hline 0.3 & 1.33 & 22.8 & 19.8 & 3.0 & 2.70 & 100 & 30 & Silty sand & 01 & 13.6 & - \\
\hline 0.6 & 1.26 & 36.1 & 30.6 & 5.5 & 2.71 & 97 & 21 & Silty sand & 17 & 8.08 & 50 \\
\hline 0.8 & 1.45 & 29.5 & 23.3 & 6.2 & 2.76 & 98 & 33 & Silty sand & 22 & 3.02 & - \\
\hline 1.1 & 1.45 & 32.9 & 23.3 & 9.7 & 2.76 & 92 & 34 & Clayey sand & 21 & 0.80 & 41 \\
\hline 1.6 & 1.50 & 31.0 & 24.1 & 6.9 & 2.75 & 93 & 30 & Clayey sand & 20 & 0.52 & - \\
\hline 2.7 & - & - & - & - & - & - & - & - & - & - & 11 \\
\hline
\end{tabular}

significant deterioration. The laboratory test results are shown in Table 3.

The results show that the nonwoven geotextile bag material used in this work, even after 3 years of field exposure, has not shown signs physical deterioration with only $15 \%$ drop in its strength.

\section{Effect of the Protection Measures on Siltation and Flow Deflection of the River}

The river Jiyabharali in the year 2012 breached about $500 \mathrm{~m}$ of an earthen dyke constructed in the western bank. The dyke was primarily responsible for protection of the
Tezpur University and its adjoining areas from river Jiya Bharali flood. The WRD, along with works for closing the breach of the dyke, carried out a river bank protection work using geotextile bags in the location. The change in river flow pattern near the bank due to the bank protection work and the resultant siltation was studied in this work.

Due to installation of the launching apron in the river bed the velocity of flow gets reduced near the bank and silt deposition starts. With the increase in volume of the silt deposit the main stream flow direction of the river gradually gets deflected away from the bank and siltation area slowly widens. As the water level recedes after flood the areas experiencing highest silt deposit appear first as a sand bar over the river water surface. River water continues to 


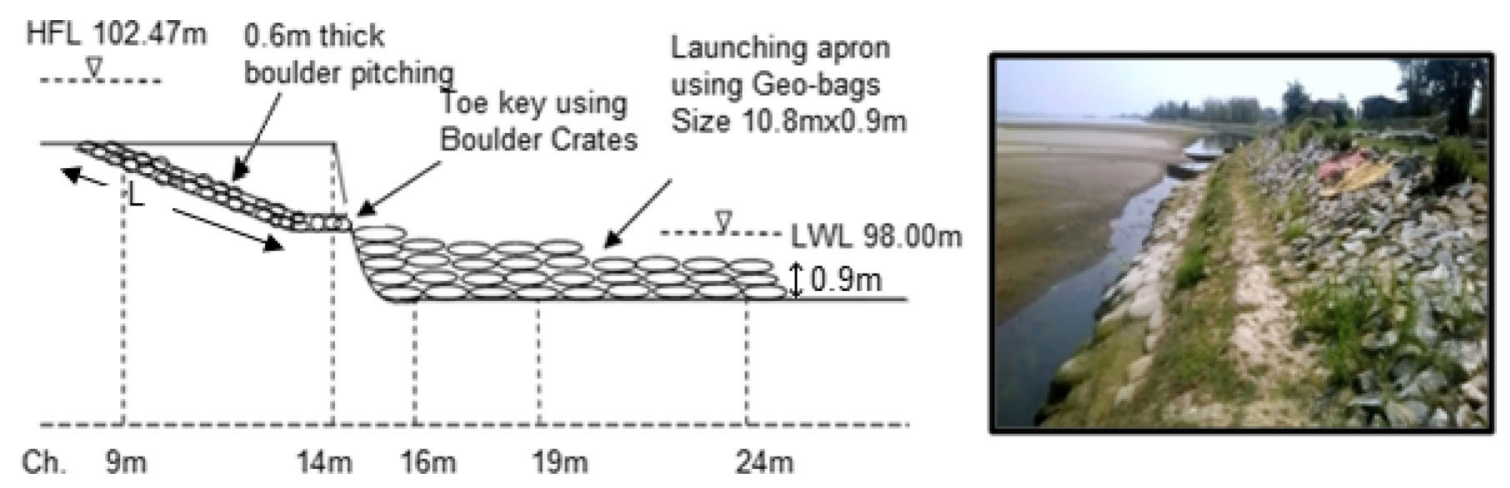

Fig. 3 Details of the bank protection work installed using geotextile bags in Jia Bharali river

Table 2 Technical details of the bank protection work installed by Water Resource Department, Assam

Site: Jiyabharali river embankment at Dikoraijan near Tezpur University

Length of mitigated area: $650 \mathrm{~m}$

Type of mitigation measures: boulder rip-rap and geotextile bags

Year of work: 2012-2013

Boulder pitching

Slope of pitching: $2 \mathrm{H}: 1 \mathrm{~V}$

Launching apron with geotextile bags

Pitching thickness: $0.60 \mathrm{~m}$

Length of launching apron: $10.80 \mathrm{~m}$

$0.075 \mathrm{~m}$ of thick metal filter bed

Thickness of apron: $0.90 \mathrm{~m}$ (3 layers of geotextile bags each $0.3 \mathrm{~m}$ thick)

Average pitching length ( $L$ in Fig. 3): 5.4 m

Geotextile bag filling: local sand packed to density $1.90 \mathrm{~g} / \mathrm{cc}$.

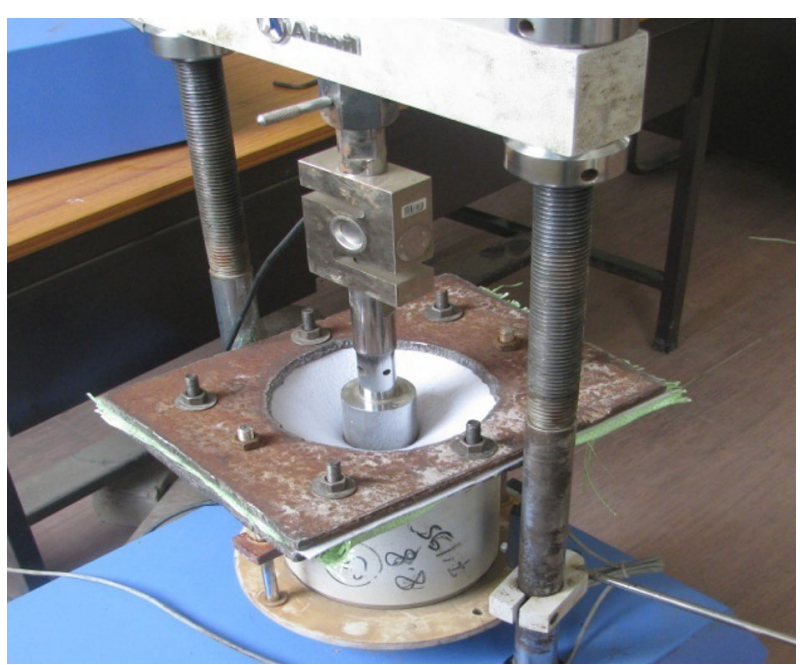

Fig. 4 CBR testing of the geotextile used

flow around these small sand bars. As the water recedes further the next level of silt deposit areas emerge above the water surface. More siltation areas emerge as the river water level continues to recede until it reaches LWL. Thus, the different ground elevations of bars in the river represent different stages of their formation with respect to time. The profile of this progressive formation of sand bars as a result of induced siltation can indirectly be used to estimate the change in flow pattern of the river after installation of the bank protection works.

In order to estimate the extent of this progressive sand bar formation contour drawing of the char area was prepared through detailed ground surveying. The sand bar which was formed after installation of bank protection measures in 2013 was surveyed in January 2014 in this work. The surveying was done using digital theodolite by dividing the entire area into $20 \mathrm{~m}$ grids. The contour map was drawn adopting the method of interpolation with a contour interval of $25 \mathrm{~cm}$. Contours at elevations 99.25 , 99.00, 98.75, 98.50, 98.25 and $98.00 \mathrm{~m}$ (LWL) are shown in Fig. 5a-f.

\section{Change in River Flow Direction After Installation of Protection Measure}

The change in flow pattern of Jia Bharali river in the study area during the period after installation of the protection measure is studied with the help of satellite photos of the river available in Google Earth. With the help of Google Earth satellite photos taken in March 2013 and March 2015 the flow pattern of the river channels and the sand bars as existed in March 2015 and March 2013 are traced out in 
Table 3 Results of laboratory tests carried out on the geotextile bag materials

\begin{tabular}{lll}
\hline Properties & \multicolumn{2}{l}{ Test results of the geotextile bag material used in the project ${ }^{\mathrm{a}}$} \\
\cline { 2 - 3 } & $\begin{array}{l}\text { Unused material samples } \\
\text { (stored in room condition) }\end{array}$ & $\begin{array}{l}\text { Material used in field in the year 2012 } \\
\text { (3 years of field exposure) }\end{array}$ \\
\hline Mass per unit area $\left(\mathrm{g} / \mathrm{m}^{2}\right)$ & 326 & 300 \\
Thickness $(\mathrm{mm})$ & 2 & 2 \\
CBR puncture strength $(\mathrm{N})$ & 1400 & 1200 \\
Tensile strength $(\mathrm{kN} / \mathrm{m})$ & 8.9 & 7.6 \\
Strain at failure $(\%)$ & 33 & 27 \\
\hline
\end{tabular}

${ }^{\text {a }}$ Project executed in year 2012-2013 and materials tests conducted in March 2016

Fig. 6a, b, respectively. A comparison of Fig. 6a, b shows fresh erosion during the period together with formation of new sand bars. The extent of the areas affected by fresh erosion due to change in flow direction of the river channels and fresh siltation areas during the period from 2013 to 2015 are determined and shown in Fig. 6c. The grid in the figures shows the latitude-longitude of the study area.

\section{Discussion}

Two important aspects of river bank material strength are erodibility and shear strength of the bank soil. Bank soil with low cohesion and low plasticity index $(\mathrm{PI}<15)$ are more susceptible to erosion [15]. The bank under study is constituted of soil having low PI $(<10)$ and cohesion value making it erodible. The shear parameters are also found to be very low. The in situ vane shear tests show slightly higher shear strength. The reason for this may be loss of strength due to remoulding of the soil sample. The vane shear strength record shows a sharp fall in the shear strength as the soil becomes saturated. This indicates the sharp loss of stability of the bank soil in the submerged condition during flood events.

As the velocity of flow is reduced after installation of the bed apron the first sign of siltation is seen near the upstream end of the bed apron (Fig. 5a). Figure 5a also shows initiation of mid-channel siltation at a location about $300 \mathrm{~m}$ away from the bank indicating deflection of the river flow direction away from the protection work. As the flood water recedes the siltation area grows around the initial mid-channel sand bar and also near the downstream side of the launching apron (Fig. 5b-d). It indicates gradual deflection of the river water flow channel away from the bank. Figure 5 shows that the zone of influence of the bed protection work in the form of launching apron extends up to distance $350 \mathrm{~m}$ from the bank into the river which is nearly 30 times that of the $10.5 \mathrm{~m}$ width of the launching apron.
As the flood water recedes the flow of water is gradually deflected away from the bank, the detour further initiates siltation in the upstream of the protection measure and the sand bar progressively develops much beyond the upstream end point of the protection measure.

Figure 5e, f shows that although the launching apron successfully diverted the river water flow channel away from the bank near the upstream end of the protection measure and resulted in development of a new sand bars no siltation occurs immediately beyond the downstream end of the protection measure and the river channel comes sharply back towards the bank just beyond the downstream end of the bed apron. Since the bank soil is erodible, as evident from the geotechnical testing, this sharp flow of the river towards the bank downstream of the protection work has made it highly vulnerable to impinging flow erosion.

Figure 6 clearly shows that the river channel has sharply come back into the bank. This channel has started fresh bank erosion in the immediate downstream of the protection work.

Jia Bharali river, after installation of the protection measure in the western bank, has progressively come closer to the same bank in the downstream of the protection work. It, therefore, has further increased the susceptibility of the bank to erosion in immediate downstream of the protection measure. In this downstream section of the river, during the period of 2 years from 2013 to 2015, the river has changed course towards the western bank resulting in bank erosion and formation of mid-channel sand bars. This has created an urgent need to protect the river bank further downstream of the protection work under study.

\section{Conclusions}

The study on the effect of installation of river bank protection measure along with bed protection using geotextile bags in river Jia Bharali has revealed the following important conclusions: 
Fig. 5 Sand bar having elevation a $>99.25 \mathrm{~m}$; b $>99.00 \mathrm{~m} ; \mathbf{c}>98.75 \mathrm{~m}$; d $>98.50 \mathrm{~m}$; e $>98.25 \mathrm{~m}$; f $>98.00 \mathrm{~m}$

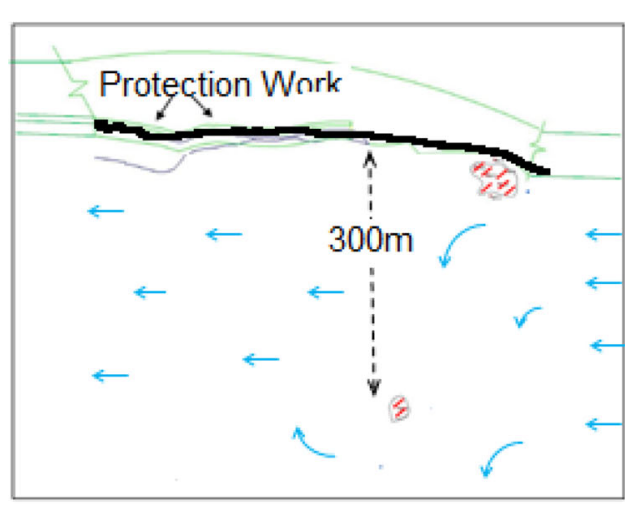

(a) Sand bar having elevation $>99.25 \mathrm{~m}$

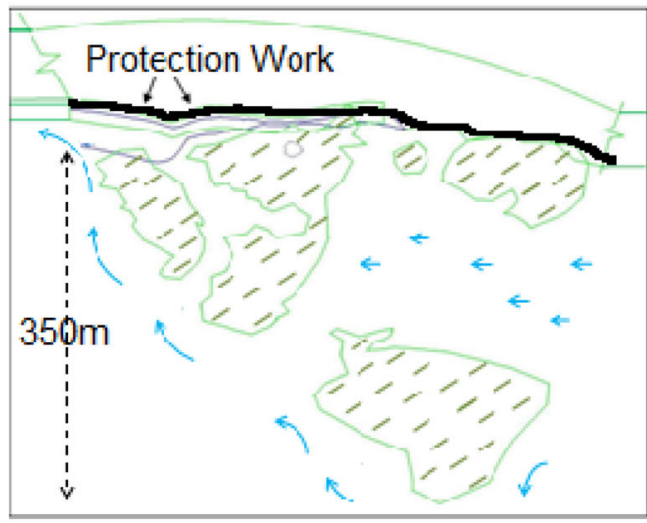

(c) Sand bar having elevation $>98.75 \mathrm{~m}$

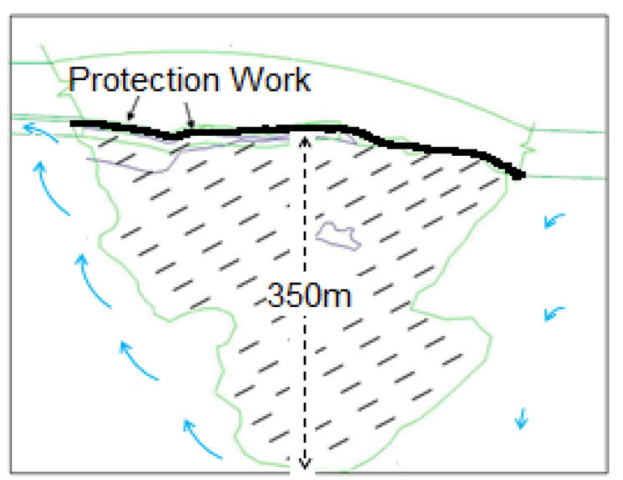

(e) Sand bar having elevation $>98.25 \mathrm{~m}$

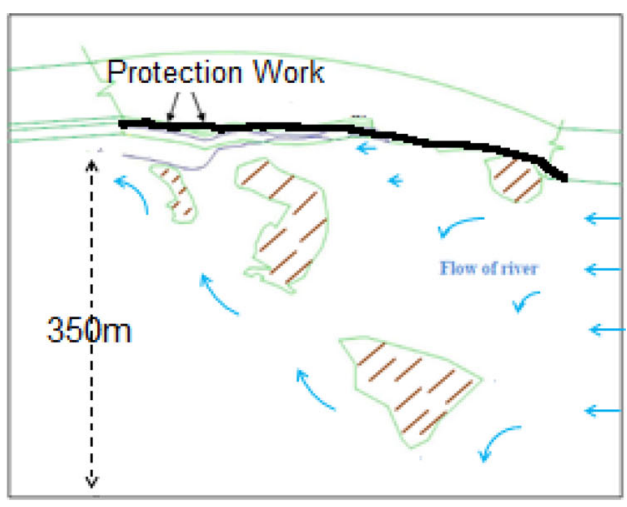

(b) Sand bar having elevation $>99.00 \mathrm{~m}$

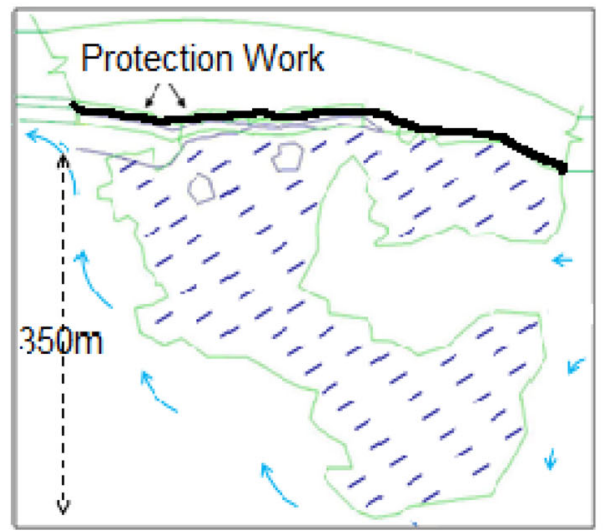

(d) Sand bar having elevation $>98.50 \mathrm{~m}$

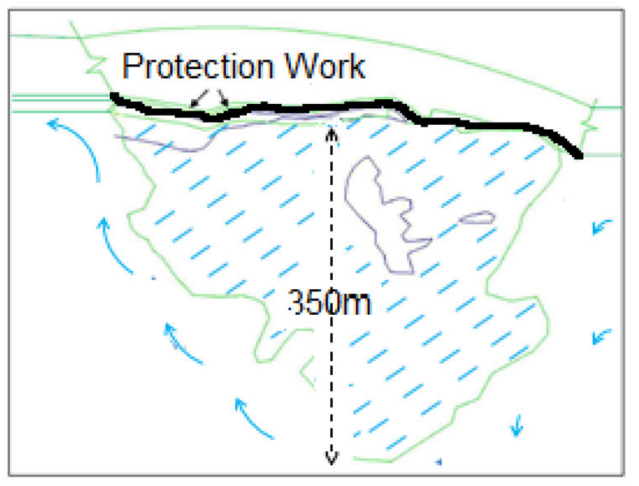

(f) Sand bar having elevation $>98.00 \mathrm{~m}$
1. The protection work has successfully diverted the river from the protected bank and resulted in siltation creating a sand bar extending to a distance nearly 30 times that of the width of the launching apron.

2. Although flow of the river is diverted from the bank in the protected stretch the diverted steam has sharply come back towards the bank just beyond the downstream end of the protection work, thus, rendering the bank downstream of the protection work vulnerable to erosion.

3. The poor geotechnical properties of the bank subsoil has made it further susceptible to erosion.

4. The protection work in its downstream has adversely affected the very river bank causing erosion and gradual shifting of the major stream of the river into the bank within a period of 3 years. 
Fig. 6 Flow pattern and sand bars of Jia Bharali river a in the study area as on March 2015; b in the study area as on March 2013. c Fresh change in flow direction and siltation areas during the period from 2013 to 2015

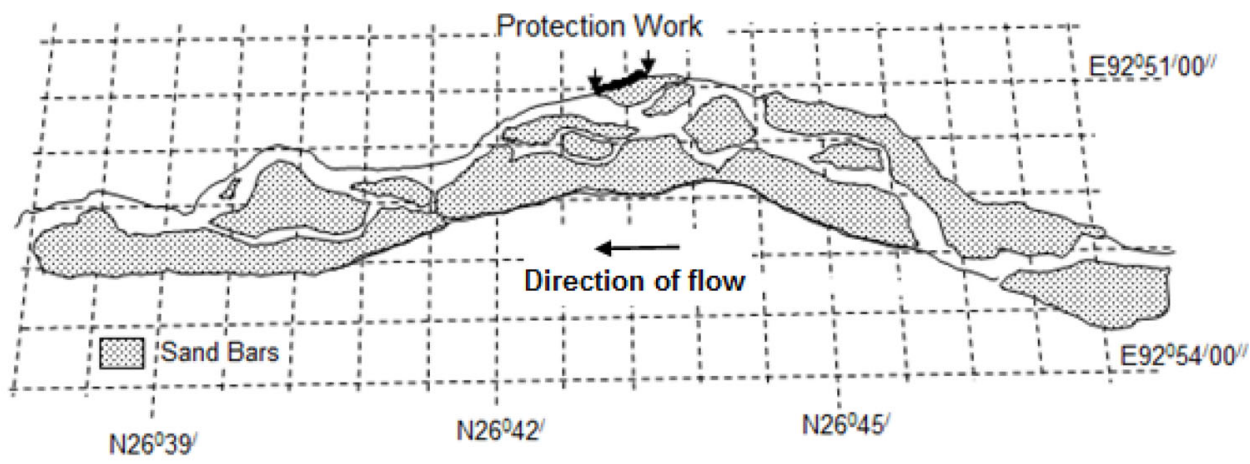

(a) Flow pattern and sand bars of Jia Bharali river in the study area as on March 2015

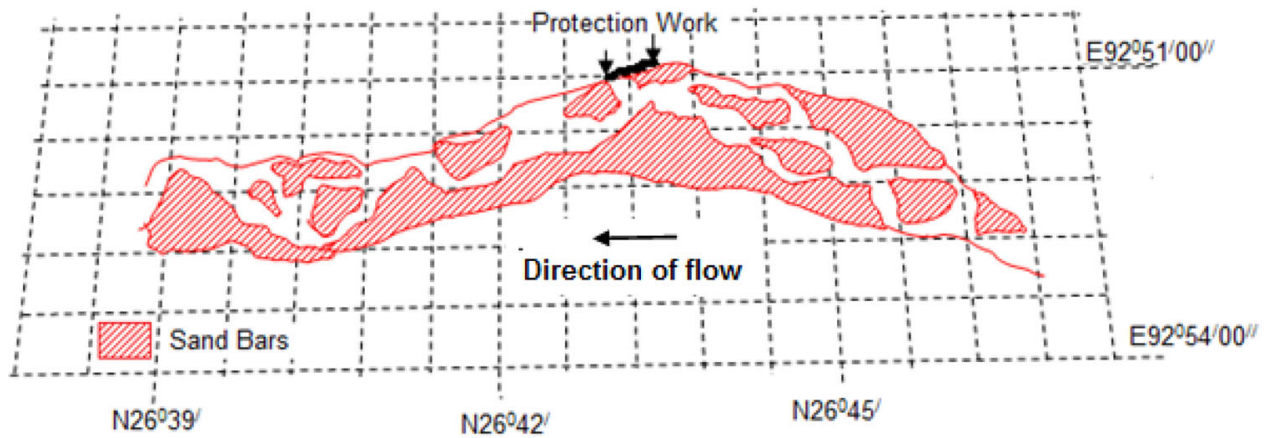

(b) Flow pattern and sand bars of Jia Bharali river in the study area as on March 2013

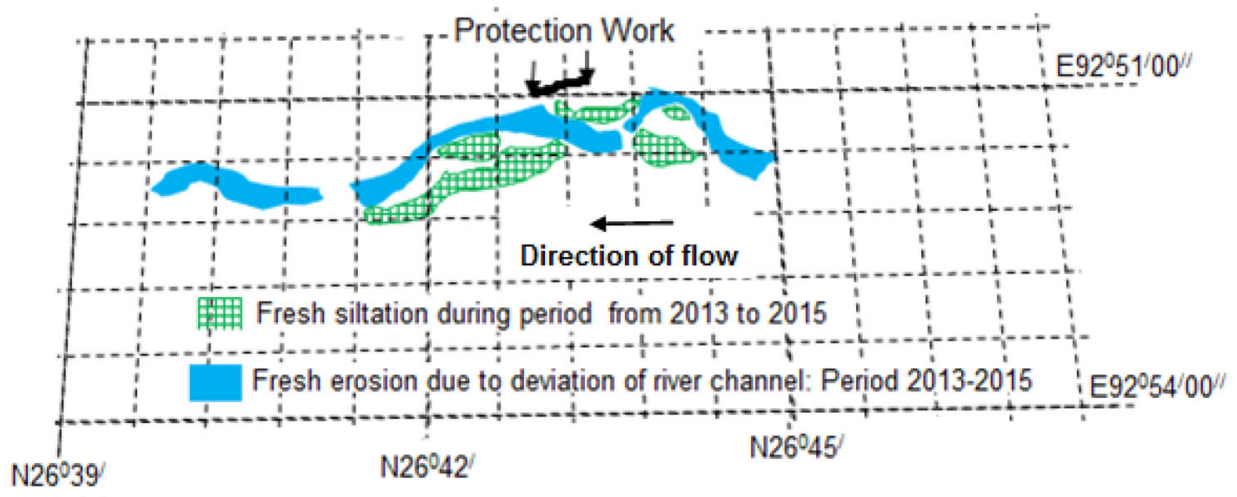

(c) Fresh change in flow direction and siltation areas during the period from 2013 to 2015
From this study it is concluded that short length bank protection measures with bed apron using geotextile bags, although effective in protecting an intended area, has the potential of pushing the erosion problem towards the downstream area of the same bank. Such project planning needs to include measures to reduce downstream bank erosion particularly if the geotechnical properties of the bank soil in the downstream stretch are found to be poor.

\section{References}

1. Mitra AK (2010) Brahmaputra river-flood and erosion management in Assam. In: Proceeding of 26th National Convention of Civil Engineering organized by the Institution of Engineers (India), Guwahati, pp 59-73
2. Kotoky P, Bezbaruah D, Baruah J, Sarma JN (2005) Nature of bank erosion along the Brahmaputra river channel, Assam, India. Curr Sci 88(4):634-640

3. Gogoi C, Goswami DC (2013) A study on bank erosion and bank line migration pattern of the Subansiri river in Assam using remote sensing and GIS technology. Int $\mathbf{J}$ Eng Sci 2(9):1-6 (ISSN(e): 2319-1813)

4. Sarkar A, Garg RD, Sharma N (2012) RS-GIS based assessment of river dynamics of Brahmaputra river in India. J Water Resour Prot 4:63-72. doi:10.4236/jwarp.2012.42008

5. Goswami U, Sarma JN, Patgiri AD (1999) River channel changes of the Subansiri in Assam, India. Geomorphology 30:227-244

6. Talukdar R (2011) Geomorphological study of the Jia Bharali river catchment, N.E. India. PhD thesis, Gauhati University. http://hdl.handle.net/10603/5456

7. Gogoi C (2013) Environmental geomorphology and natural hazards of the lower Subansiri basin. PhD thesis, Gauhati University. http://hdl.handle.net/10603/50837 
8. Mondal M, Bhunia GS, Shit PK (2012) Vulnerability analysis of embankment breaching - a case study of Moyna drainage basin in Prurba Medinipur, West Bengal, India. Int J Geol Earth Environ Sci 2(3):89-102 (ISSN: 2277-2081)

9. Maurya S, Gupta M, Kumar N (2013) Use of geosynthetics in restoration and bank protection from Dhola-Hatiguli to Rohmoria along the river Brahmaputra - a case study. Int J Latest Trends Eng Technol 3(1):136-144 (ISSN: 2278-621X)

10. Maurya S, Kumar N, Gupta M (2013) Use of geobags for restricting the flow of river Dibang, a tributary of river Brahmaputra, Assam-a case study. In: Proceedings Indian geotechnical conference, Roorkee, pp 1-6

11. Iverson NR (2010) Shear resistance and continuity of subglacial till: hydrology rules. J Glaciol 56(200):1104-1114
12. Das N, Wadadar S (2012) Impact of bank material on channel characteristics: a case study from Tripura north-east India. Arch Appl Sci Res 4(1):99-110

13. IS 4434 (1978) Code of practice for in-situ vane shear test for soils. Bureau of Indian Standards, New Delhi

14. Rajagopal K (2016) Testing of geosynthetics. nptel.ac.in/courses/ 105106052/downloads/Lecture-6.pdf. Accessed 28 Mar 2016

15. Throne CR (1981) Field measurements of rates of bank erosion and bank material strength, erosion and sediment transport measurement. Proceedings of the Florence symposium, IAHS publication no. 133:503-511 